\title{
SISTEM ELECTRONIC-HUMAN RESOURCE MANAGEMENT (e-HRM) MENGGUNAKAN METODE RAPID APPLICATION DEVELOPMENT (Studi Kasus: PT. Andesta Mandiri Indonesia)
}

\author{
${ }^{1}$ Andri Hairiyadi, ${ }^{2}$ T. Khairil Ahsyar \\ ${ }^{1,2}$ Program Studi Sistem Informasi, Fakultas Sains dan Teknologi UIN Suska Riau \\ Jl. HR Soebrantas KM.18 Panam Pekanbaru - Riau \\ e-mail: ${ }^{1}$ andrihairiyadi@gmail.com, ${ }^{2}$ tengkukhairil@uin-suska.ac.id
}

\begin{abstract}
ABSTRAK
PT. Andesta Mandiri Indonesia merupakan salah satu perusahaan outsourching yang bergerak di bidang penyaluran tenaga kerja. Dalam proses pengelolaan data karyawan, data area kerja, data kontrak kerja, data lowongan, dan surat lamaran pekerjaan sudah terkomputerisasi, tetapi hanya sebatas menggunakan Microsoft Excel. Masalah yang sering dialami yaitu, sulitnya merekap data laporan karyawan karena banyaknya data lamaran kerja, data karyawan dan data area kerja yang sudah bekerja sama, dan juga tidak adanya pemberitahuan masa kontrak kerja karyawan yang hampir habis sehingga berdampak pada kesiapan pihak manajemen dalam melakukan negosiasi kembali. Tujuan dari penelitian adalah membangun sistem e-HRM berbasis web yang berguna untuk memudahkan tugas HRD dalam mengelola data. Sistem e-HRM merupakan solusi untuk mengatasi masalah yang dihadapi pada PT. AMI. Library javacript leaflet digunakan untuk menampilkan peta persebaran titik area kerja. Perancangan sistem menggunakan metode Rapid Application Development yang memiliki tiga tahapan yaitu Required Planning, Workshop Design, dan Implementation. Hasil uji Black Box yang dilakukan terhadap fitur yang terdapat pada sistem e-HRM yang dibuat berjalan 100\%. Berdasarkan hasil pengujian yang telah dilakukan dapat diambil kesimpulan bahwa sistem e-HRM dapat berjalan dengan baik, sehingga sistem dapat mempermudah pihak perusahaan dalam melakukan proses management karyawan.
\end{abstract}

Kata Kunci: Black Box, e-HRM, Library javacript leaflet, Outsourching , Rapid Application Development.

\section{A. PENDAHULUAN}

PT. Andesta Mandiri Indonesia (PT.AMI) merupakan salah satu perusahaan outsourcing yang bergerak di bidang penyaluran tenaga kerja yang bertujuan untuk menjadi perusahaan penyedia tenaga kerja yang terpercaya, terkemuka serta handal dalam bidang pelayanannya dan beroperasi sebagai perusahaan penyedia tenaga kerja yang terkemuka dengan jaringan luas oleh tenaga kerja yang terampil, jujur, berdisiplin tinggi dan bertanggung jawab serta memiliki peralatan dan perlengkapan yang modern. PT.AMI beralamat di jalan Rambutan No.5 Kelurahan Sidomulyo Timur Kecamatan Marpoyan Damai Pekanbaru, Riau. Perusahaan ini menyalurkan tenaga kerja seperti cleaning service, security, helper, supervisor cleaning service, supervisor security dan driver.

PT. AMI merupakan suatu perusahaan yang berpusat di Pekanbaru, Riau. Dari awal berdiri sampai pada saat ini, PT. AMI telah memiliki 585 orang tenaga kerja. Tenaga kerja tersebut terbagi ke dalam beberapa jenis pekerjaan yang tersebar di kantor PT. AMI itu sendiri dan juga di area kerja. Pada saat ini terdapat 62 area kerja yang sudah bekerja sama yang terdiri dari 49 perusahaan, 7 rumah sakit, 4 pusat perbelanjaan, 2 sekolah dan 1 mesjid. Area tersebut tersebar di daerah Riau, yaitu daerah Pekanbaru sebayak 39 area dan luar Pekanbaru terdapat 11 area, maupun di luar Riau terdapat 12 area kerja.

PT. AMI memerlukan sejumlah tenaga kerja dalam menjalankan proses bisnis perusahaan. Tenaga kerja berfungsi sebagai pelaksana pekerjaan yang menjadi tugas pokok perusahaan. Oleh karena itu proses rekrutmen sangatlah diperlukan untuk mendapatkn tenaga kerja yang sesuai dengan yang diharapkan perusahaan. Pada proses rekrutmen yang sedang berjalan pada saat ini dimulai dari tahap informasi lowongan, seleksi pelamar dan training bagi tenaga kerja baru. Kebutuhan tenaga kerja yang dimiliki PT. AMI dinilai cukup banyak sehingga kegiatan rekrutmen diperusahaan ini dilaksanakan setiap hari, tergantung dari permintaan perusahaan pengguna jasa.

Berdasarkan hasil wawancara dengan ibu Isna selaku Human Resource Departement (HRD) di PT. AMI. Dalam proses pengelolaan dan peng-input-an data tenga kerja seperti data lamaran pekerjaan, biodata pribadi karyawan, jenis pekerjaan, perusahaan tempat karyawan ditempatkan dan kontrak karyawan sudah terkomputerisasi, tetapi hanya sebatas menggunakan Microsoft Excel. Data-data tersebut 
kemudian di input dan disimpan pada berkas daftar area kerja. Adapun masalah yang sering dialami oleh pihak manajemen perusahaan yaitu, sulitnya merekap data laporan tenaga kerja karena banyaknya jumlah tenaga kerja dan area kerja yang tersebar di daerah Riau maupun daerah luar Riau. Serta sulit untuk mencari data laporan tersebut dengan cara manual, dengan cara membuka dokumen berkas daftar area kerja karyawan. Terkadang pihak HRD tidak sempat dalam melakukan peng-input-an data karena banyaknya jumlah data tenaga kerja dan area kerja yang semuanya di kelola sendiri oleh HRD.

Pada saat ini sudah bayak tenaga kerja yang di kontrak kerja oleh perusahaan. Dengan adanya kerja sama ini, terdapat suatu perjanjian kontrak kerja. Kontrak kerja adalah suatu perbuatan hukum yang terjadi karena adanya kesepakatan antara dua orang atau lebih dengan maksud untuk menimbulkan kewajiban-kewajiban antara satu pihak dengan pihak lain [1]. Pada proses yang sedang berjalan pada saat ini, timbul masalah di mana tidak adanya pemberitahuan khusus untuk melihat daftar kontrak kerja karyawan dan sisa waktu kontrak kerja karyawan dengan perusahaan. Jika sisa masa kontrak kerja sama dengan perusahaan hampir habis, pihak manajemen tidak mendapatkan notifikasi dari sistem yang saat ini digunakan, sehingga berdampak pada kesiapan pihak manajemen untuk melakukan negosiasi kembali dengan tenaga kerja.

Mengenai informasi lowongan pekerjaan yang ada pada PT. AMI. Saat ini informasi lowongan yang tersedia masih di tulis di surat kabar atau media sosial lainnya, dan untuk pengiriman surat lamaran pekerjaan masih bersifat manual dimana setiap pelamar pekerjaan mengirimkan berkas lamaran pekerjaan tersebut ke alamat PT. AMI. Untuk berkas lamaran harus di cek satu persatu, sehingga mengakibatkan data lamaran pekerjaan yang menumpuk dan tak jarang lamaran pekerjaan tersebut terselip atau hilang.

Permasalahan yang terakhir yang sering dialami oleh pihak HRD perusahaan dengan sistem yang digunakan saat ini yaitu, tidak sempatnya dalam membuat laporan, karena banyaknya jumlah karyawan dan area kerja yang ada, baik itu laporan karyawan, area kerja dan laporan kontrak kerja dan tidak jarang HRD juga ikut turun langsung ke area kerja karyawan. Sehingga menyebabkan terhambatnya proses bisnis yang sedang berjalan pada PT. AMI.

Untuk mengatasi permasalahan yang ada pada saat ini, perusahaan PT. AMI membutuhkan suatu sistem e-HRM yang dapat membantu dalam mengelola data karyawan menjadi sebuah informasi. Untuk dapat membangun sebuah sistem e-HRM, maka diperlukan sebuah metode Object Oriented Analysis and Design (OOAD) dengan model pengembangan
Rapid Application Development (RAD) dengan tahapan-tahapan requirement planing, user design, dan implementasi[2]. Dengan menggunakan metode RAD akan dicapai suatu sistem fungsional yang utuh dalam periode waktu yang relatif pendek dengan catatan, investigasi kebutuhan sistem telah diperoleh dan dipahami dengan baik [3].

Analisa dan desain sistem yang akan di rancang menggunakan alat pemodelan menggunakan Uniffied Modelling Language (UML) dengan beberapa tools perancangan use case diagram, class diagram, sequence diagram dan activity diagram[4]. Pembuatan sistem menggunakan bahasa pemograman PHP Codeigniter dengan database MySQL. Pengujian sistem menggunakan Black Box Testing.

Berdasarkan uraian latar belakang di atas dalam penelitian ini mengangkat judul rancang bangun Electronic-Human Resources Management (e-HRM) menggunakan metode Rapid Application Development (RAD) pada PT. Andesta Mandiri Indonesia.

\section{B. LANDASAN TEORI \\ B.1 Outsourcing}

Outsourcing dalam hukum ketenagakerjaan di Indonesia diartikan sebagai pemborongan pekerjaan dan penyediaan jasa tenaga kerja. Pengaturan hukum outsourcing di Indonesia di atur dalam UndangUndang Ketenagakerjaan Nomor 13 tahun 2003 (pasal 64, 65 dan 66) dan Keputusan Menteri Tenaga kerja dan Tranmigrasi Repoblik Indonesia No.Kep.101/Men/2004 Tahun 2004 tentang Tata Cara Perijinan Perusahaan Penyedia Jasa Pekerja/Buruh[5].

Undang-Undang Nomor 13 Tahun 2003 Tentang Ketenagakerjaan, kata outsourcing tidak disebut secara langsung, namun disebut sebagai "menyerahkan sebagian pekerjaan kepada perusahaan lain"[5]. Outsourcing merupakan istilah yang lazim digunakan dalam dunia indrustri dengan makna yang kurang lebih sama dengan yang diuraikan oleh Undang-Undang Ketenagakerjaan.

\section{B.2 Human Resource Management}

Sumber daya manusia atau human resource mengandung dua pengertian. Pertama, Sumber Daya Manusia (SDM) mengandung pengertian usaha kerja atau jasa yang dapat diberikan dalam proses produksi. Dalam hal ini SDM mencerminkan kualitas usaha yang diberikan oleh seseorang dalam waktu tertentu untuk menghasilkan barang dan jasa. Kedua dari SDM menyangkut manusia yang mampu bekerja untuk memberikan jasa atau usaha kerja tersebut. Mampu bekerja berarti mempu melakukan kegiatan yang mempunyai nilai ekonomis, yaitu kegiatan tersebut menghasilkan barang atau jasa untuk memenuhi kebutuha masyarakat[6]. 


\section{B.3 Electronic-Human Resource Management (e- HRM)}

e-HRM merupakan sebuah tool yang berbasis web yang secara otomatis mendukung proses sumber daya manusia[7]. e-HRM merupakan sebuah jalan untuk mengemplementasikan strategi HRM, kebijakan dan praktek dalam organisasi secara sadar dan didukung dengan arahan penuh dari dasar teknologi berbasis web.

Tujuan akhir dari e-HRM adalah[8]:

1. Meningkatkan orientasi strategi dari HRM.

2. Mengurangi biaya efisiensi keuntungan.

3. Fasilitas untuk manajemen dan karyawan.

\section{B.4 Rekrutmen}

Sumber daya manusia yang tangguh merupakan salah satu unsur penentu perusahaan akan dapat bersaing di pasar global. Perusahaan harus mampu membangun kepercayaan atau nilai di kalangan karyawan. Yaitu tegas untuk selalu bekerja berbasis standar mutu tinggi. Semakin tinggi standar, maka akan semakin berpeluang perusahaan untuk makin maju[9].

Perekrutan merupakan hal yang lebih komplek dari apa yang dipikirkan oleh seorang manajer. Kegiatan ini tidak hanya melibatkan penempatan iklan atau memanggil agen pekerjaan. Pertama, upaya perekrutan harus sesuai dengan rencana strategis perusahaan. Kedua, beberapa metode perekrutan lebih baik dari yang lain, bergantung pada jenis pekerjaan yan di rekrut dan yang menjadi sumber daya. Ketiga, keberhasilan rekrutmen tergantung pasa luasan area masalah dan kebijakan non-rekrutmen SDM. Yang terpenting adalah rencana perekrutan harus konsistem secara internal dan sesuai dengan strategi perusahaan [10].

\section{B.4.1 Proses Rekrutmen}

Salah satu komponen atau unsur dalam sistem rekrutmn dalam suatu organisasi atau perusahaan yaitu keputusan dimana mencari pelamar. Agar manajemen dapat menjalankan tugasnya dengan efektif dan efisien, maka mereka perlu mengetahui dan memahami berbagai sumber rekrutmen dengan mengingat uraian jabatan dan spesifikasi jabatan. Perekrutan tenaga kerja dapat dilakukan melalui dua cara, yaitu internal dan external [11].

\section{B.4.2 Seleksi}

Seleksi merupakan kegiatan dalam manajmen sumber daya manusia yang dilakukan setelah rekrutmen selesai dilaksanakan. Seleksi merupakan suatu cara pemilihan tenaga kerja yang sudah tersedia. Pada dasarnya tujuan dari seleksi adalah untuk mendapatkan tenaga kerja yang memenuhi syarat dan memiliki kualifikasi yang sesuai dengan kebutuhan organisasi atau perusahaan.

\section{B.4.3 Pelatihan/Training}

Pelatihan merupakan suatu proses dimana orang-orang mencapai kemampuan tertentu untuk membantu mencapai organisasi. Oleh karena itu, proses ini terikat dengan berbagai tujuan organisasi, pelatihan dapat dipandang secara sempit maupun luas. Secara terbatas, pelatihan menyediakan para pegawai dengan pengetahuan secara spesifik yang dapar diketahui serta keterampiilan yang digunakan dalam pekerjaan saat ini. Terkadang ada batasan yang ditarik antara batasan dan pengembangan, dengan pengembangan yang bersifat lebih luas dalam cakupan serta memfokuskan pada individu untuk mencapai kemampuan baru yang berguna baik bagi pekerjaannya saat ini maupun dimasa mendatang[12].

\section{B.4.4 Kontrak Kerja/Perjanjian Kerja}

Perjanjian kerja diatur secara khusus pada Bab VII KUHP tentang persetujuan-persetujuan untuk melakukan pekerjaan. Menurut Pasa 1601a KUHP, yang dimaksud dengan perjanjian kerja ialah suatu perjanjian dimana pihak yang satu, buruh, mengikatkan diri untuk bekerja pada pihak yang lain, majika, selama suatu waktu tertentu, dengan menerima upah. Sedangkan dalam Pasal 1 angka 14 Undang-undang Nomor 13 Tahun 2003 tentang Keenagakerjaan, perjanjian kerja merupakan perjanjian antara pekerja/buruh dengan pengusaha atau pemberi kerja yang memuat syarat-syarat kerja, hak dan kewajiban para pihak[13].

\section{B.4.5 Perlindungan Karyawan}

Perlindungan tenaga kerja merupakan perlindungan yang diupayakan untuk menjaga hakhak dasar dari pekerja. Tujuan perlindungan tenaga kerja menurut [14] ialah untuk menjamin berlangsungnya sistem hubungan kerja secara harmonis tanpa disertai adanya tekanan dari pihak yang kuat kepada pihak yang lemah.

Perlindungan tenaga kerja merupakan salah satu tujuan dari pembangunan ketenagakerjaan. Pembangunan ketenagakerjaan merupakan salah satu bagian dari pembangunan nasional. Inilah sebabnya perlindungan tenaga kerja merupakan hal yang perlu diperhatikan serius atas pelaksanaan karena dapat menunjang pembangunan nasional. Tujuan pembangunan ketenagakerjaan adalah:

1. Memberdayakan dan mendayagunakan tenaga kerja secara optimal dan manusiawi.

2. Mewujudkan pemerataan kesempatan kerja dan penyedia tenaga kerja yang sesuai kebutuhan pembangunan nasional dan daerah.

3. Memberikan perlindungan kepada tenaga kerja dalam mewujudkan kesejahtraan.

4. Meningkatkan kesejahteraan tenaga kerja dalam mewujudkan kesejahtraan. 
Jurnal Ilmiah Rekayasa dan Manajemen Sistem Informasi, Vol. 5, No. 2, Agustus 2019, Hal. 126-135

e-ISSN 2502-8995 p-ISSN 2460-8181

\section{B.5 Rapid Application Development (RAD)}

RAD merupakan suatu pendekatan berorientasi objek terhadap pengembangan sistem yang mencakup suatu metode pengembangan serta perangkat- perangkat lunak[2]. RAD menggunakan metode berorientasi objek. Ada tiga fase dalam RAD yang dapat dilihat pada Gambar 1.

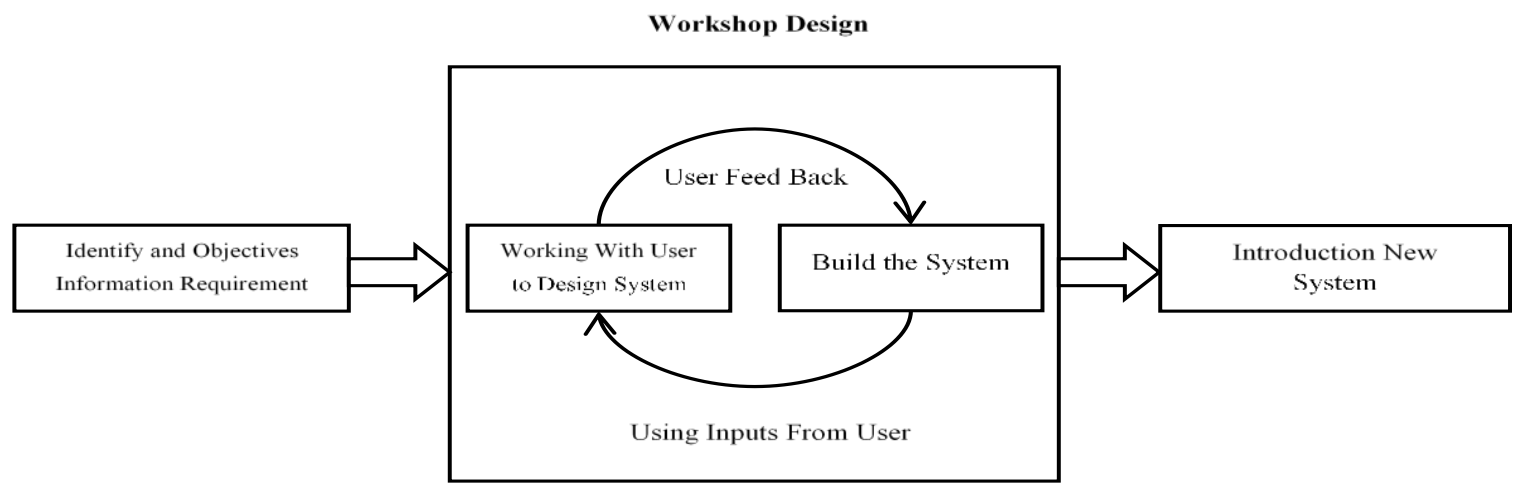

Gambar 1 Fase-Fase Model RAD

[2]

Dari gambar diatas dapat dilihat ada tiga fase utama dari merode RAD, diantaranya:

1. Requrement Planning

Dalam fase ini, penganalisis dan pengguna bertemu untuk mengidentifikasikan tujuan-tujuan plikasi atau sistem serta untuk mengidentifikasikan syarat-syarat informasi yang ditimbulkan dari tujuan-tujuan tersebut.

\section{Workshop Design}

Fase ini adalah fase untuk merancang dan memperbaiki yang bisa digambarkan sebagai workshop. Selama workshop Desain RAD, pengguna merespon working prototype yang ada dan penganalisis memperbaiki modul-modul yang dirancang berdasarkan respon pengguna.

\section{Implementasi}

Dalam fase ini anda dapat melihat bahwa penganalisis bekerja dengan para pengguna secara intens selama workshop untuk merancang aspekaspek bisnis dan nonteknis dari perusahaan.

\section{B.6 Leaflet Javascript}

Leaflet merupakan perpustakaan open source javascript yang membantu pembuatan peta pada halaman web menjadi lebih mudah. Sebagai software open source berarti script yang terdapat pada Leaflet dapat dengan mudah untuk dilihat cara kerjanya, siapa pun dapat menggunakannya dan yang lebih penting siapa pun dapat berkontribusi pada proyek dengan perbaikan kinerja Leaflet[15]. Javascript file yang dimuat bersamaan dengan halaman web dapat menyediakan akses ke berbagai fungsi yang memungkinkan untuk menyajikan peta.

\section{METODOLOGI PENELITIAN}

Dalam penelitian ini ada beberapa tahap-tahap yang lakukan dalam melakukan penelitian. Adapun metodelogi penelitian yang penulis lakukan dapat ditunjukkan pada Gambar 2.

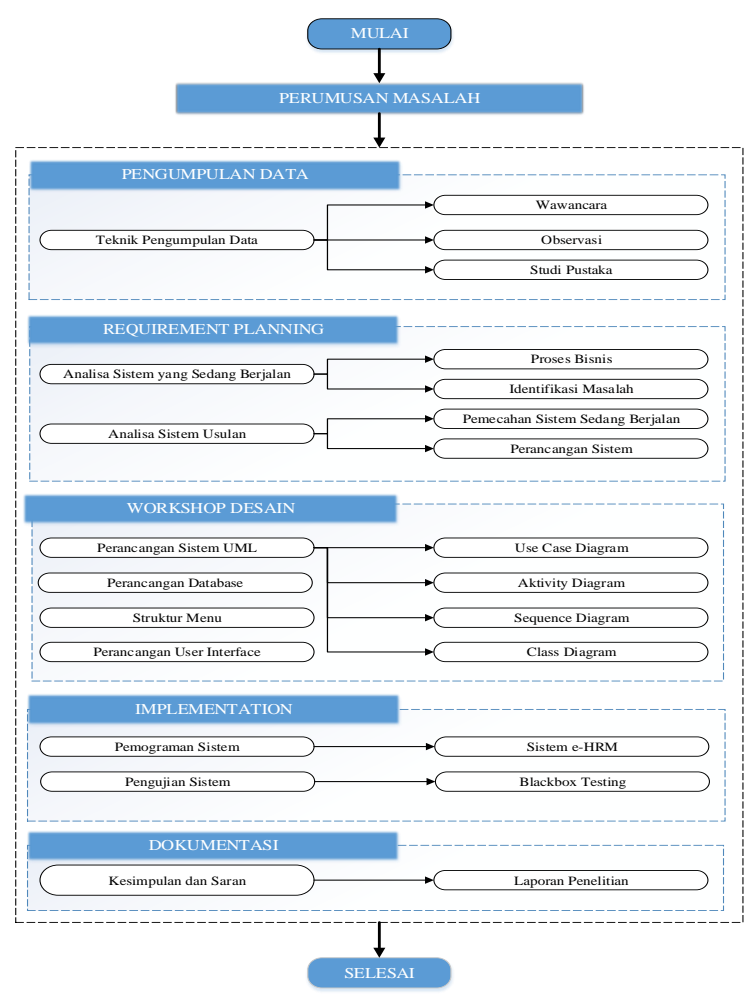

Gambar 2. Metodologi Penelitian 
Adapun tahapan-tahapan yang dilalui dari penelitian ini adalah:

\section{C.1 Tahap Perencanaan}

Merumuskan masalah tentang pengelolaan data sumber daya manusia dan mencari permasalahan yang terjadi dan kemudian diselesaikan oleh suatu sistem pengelolaan data karyawan yang terkomputerisasi.

\section{C.2 Metode Pengumpulan Data}

Tahap ini dilakukan untuk mengumpulkan datadata tentang pengelolaan data sumber daya manusia. Semua tahap pada proses pengumpulan data diperoleh dari tiga metode antara lain:

1. Wawancara

2. Observasi

3. Studi Pustaka

\section{C.3 Metode Pengembangan Sistem}

Metode pengembangan sistem yang digunakan penulis untuk merancang sistem ini menggunakan Rapid Aplication Development (RAD). Tools yang digunakan dalam perancangan sistem berupa diagram Unified model Language (UML) untuk memperlihatkan proses dan aliran data yang akan di rancang dan menggunakan Microsoft Visio sebagai tools untuk merancang diagram UML. Atom digunakan untuk mendesain aplikasi, Xampp Server v.3.3.2 sebagai webserver.

Dari Gambar 2 diatas maka dapat dilihat bahwa perancangan sistem ini menggunakan model RAD dimana dalam model ini memiliki fase-fase yang meliputi:

1) Requirement Planning

Fase ini mengedentifikasi permasalahan yang ada kemudian membuat rencana dalam menentukan tujuan serta syarat-syarat apa yang diperlukan untuk mencapai tujuan tersebut.

\section{2) Workshop Design}

Fase ini mengedentifikasi solusi alternatif dan memilih solusi terbaik. Kemudian membuat desain proses dan desain pemograman. Tujuan dari fase ini ialah untuk menganalisis masalah utama, membangun dasar arsitektur, menentukan rencana proyek, mendapatkan gambaran umum kebutuhan, persyaratan, dan fungsi-fungsi utama dari sistem.

\section{3) Implementasi}

Fase implementasi merupakan tahap akhir dari proses perancangan sistem. Dalam fase ini ada dua tahapan yang dilakukan yaitu pemograman sistem dan pengujian sistem.

\section{C.4 Dokumentasi}

Tahap dokumentasi adalah melakukan pendokumentasian dari tahap awal penelitian yang dilakukan sampai dengan tahap akhir penelitian.

\section{ANALISA DAN PERANCANGAN}

D.1 Analisa Sitem Yang Sedang Berjalan

Berikut rich picture dari sistem yang sedang berjalan yang dapat dilihat pada Gambar 3 .

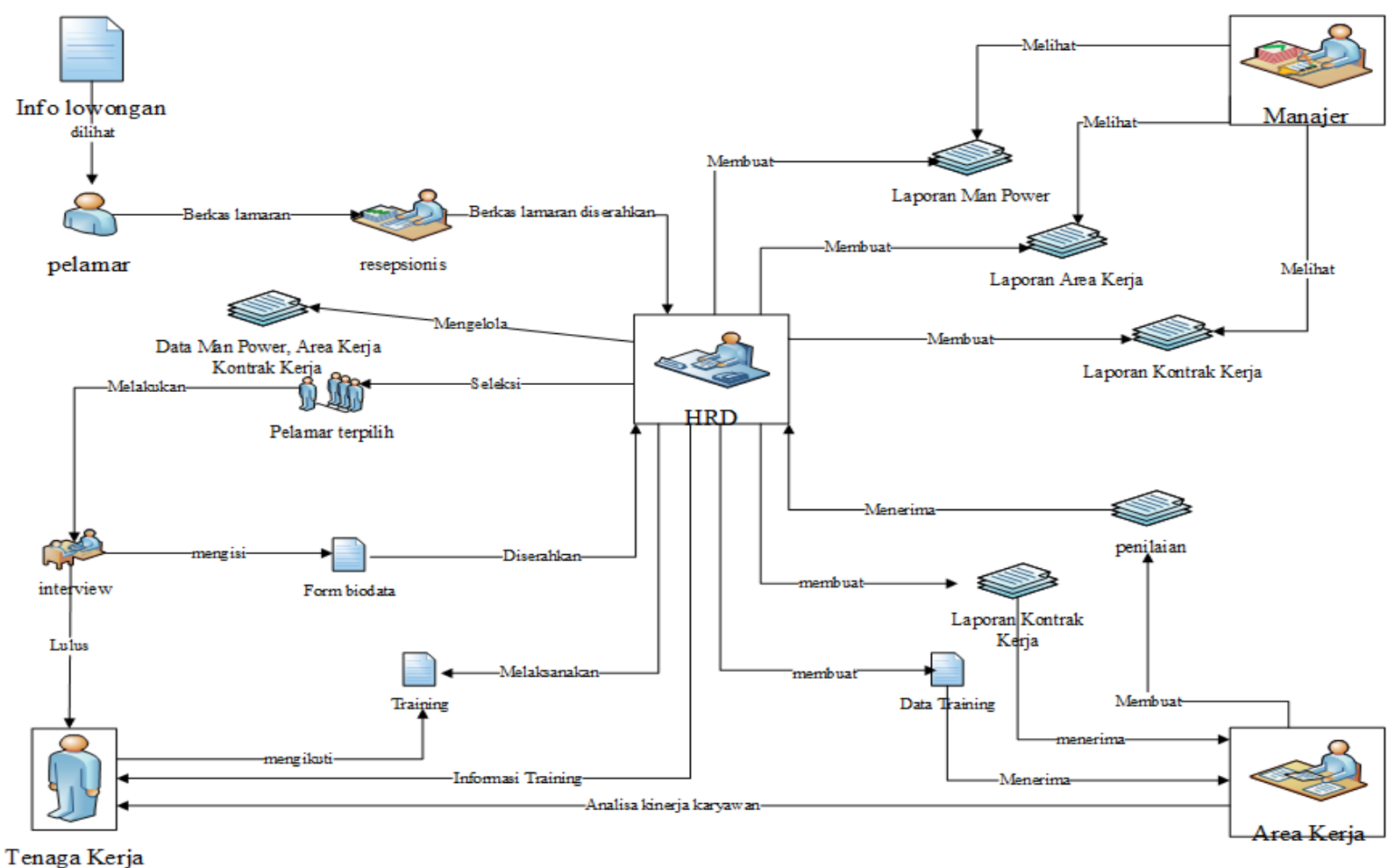

Gambar 3. Sistem yang Sedang Berjalan 
Berdasarkan Gambar 3 diatas, dapat dijelaskah bahwan PT. Andesta Mandiri Indonesia, pada saat ini tidak memiliki sistem yang baku untuk mengelola data-data karyawan, data area kerja dan data kontrak kerja. Semua dilakukan secara manual sehingga sangat menyita banyak waktu untuk pembuatan laporan yang dibutuhkan, apalagi semua di lakukan sendiri oleh HRD.

Saat ini, bagian HRD dalam melakukan proses pencatatan data dan kegiatan karyawan masih dilakukan secara manual dengan menggunakan perangkat lunak lembar tersembunyi. Penggunaan perangkat ini dalam mengelola data karyawan di PT. Andesta Mandiri Indonesia masih kurang membantu pihak HRD, khususnya dalam penyajian informasi karyawan, area kerja dan kontrak kerja karena tidak bisa menampilkan data karyawan secara lengkap untuk masing-masing karyawan seperti informasi data pribadi man power, limit kontrak, informasi area kerja man power, dan juga penilaian man power. Hal ini disebabkan karna banyaknya jumlah data yang ada, serta terpisah-pisah antara satu data dengan data lainnya. Maka dari itu manajemen membutuhkan suatu sistem yang mempu menyimpan dan mengelola data karyawan dan area kerja menjadi sebuah laporan yang bermanfaat bagi perusahaan.

Pada saat ini juga proses informasi lowongan pekerjaan yang tersedia pada PT. AMI masih di tulis di surat kabar atau media masa lainnya dan untuk pengiriman lamaran pekerjaan masih bersifat manual dimana setiap pelamar harus megirimkan berkas lamaran pekerjaan tersebut ke alamat PT. AMI pusat yang ada di Pekanbaru, sehingga menyebabkan banyaknya data lamaran kerja yang menumpuk dan tak jarang berkas lamaran pekerjaan terselip bahkan bisa hilang.

\section{D.2 Sistem Usulan}

Sistem usulan ini memiliki lima actor yaitu Pelamar, Karyawan, Admin Area, HRD dan Manajer. Tabel 1 berikut merupakan actor yang terlibat terhadap sistem.

Tabel 1 Daftar Aktor Sistem Usulan

\begin{tabular}{cl}
\hline Aktor & \multicolumn{1}{c}{ Deskripsi } \\
\hline Admin & $\begin{array}{l}\text { User Admin merupakan user yang } \\
\text { bertanggung jawab mengelola } \\
\text { sistem. }\end{array}$ \\
\hline Pelamar & $\begin{array}{l}\text { User pelamar merupakan calon } \\
\text { karyawan yang ingin bekerja di PT. } \\
\text { AMI. }\end{array}$ \\
\hline Karyawan & $\begin{array}{l}\text { User karyawan merupakan orang } \\
\text { yang sudah bekerja di PT. AMI. }\end{array}$ \\
\hline Admin & $\begin{array}{l}\text { User admin area merupakan seorang } \\
\text { Area } \\
\text { yang bertanggung jawab terhadap } \\
\text { karyawan di area kerja. }\end{array}$ \\
\hline HRD & $\begin{array}{l}\text { User manajer merupakan } \text { user yang } \\
\text { dapat mengelola data melalui } \\
\text { sistem. }\end{array}$ \\
\hline Manajer & $\begin{array}{l}\text { User manajer merupakan orang } \\
\text { yang bertanggung jawab terhadap } \\
\text { perusahaan. }\end{array}$ \\
\hline
\end{tabular}

Pada sistem yang diusulkan ini, penulis memberikan informasi mengenai perancangan sistem yang akan diajukan untuk mengatasi masalah pada proses yang sedang berjalan pada saat ini. Perancangan sistem E-HRM ini diharakan dapat membantu proses bisnis pada PT. Andesta Mandiri Indonesia sehingga lebih efektif dan efisien. Adapun rich picture untuk menggambarkan sistem usulan dalap dilihat pada Gambar 4 dibawah ini.

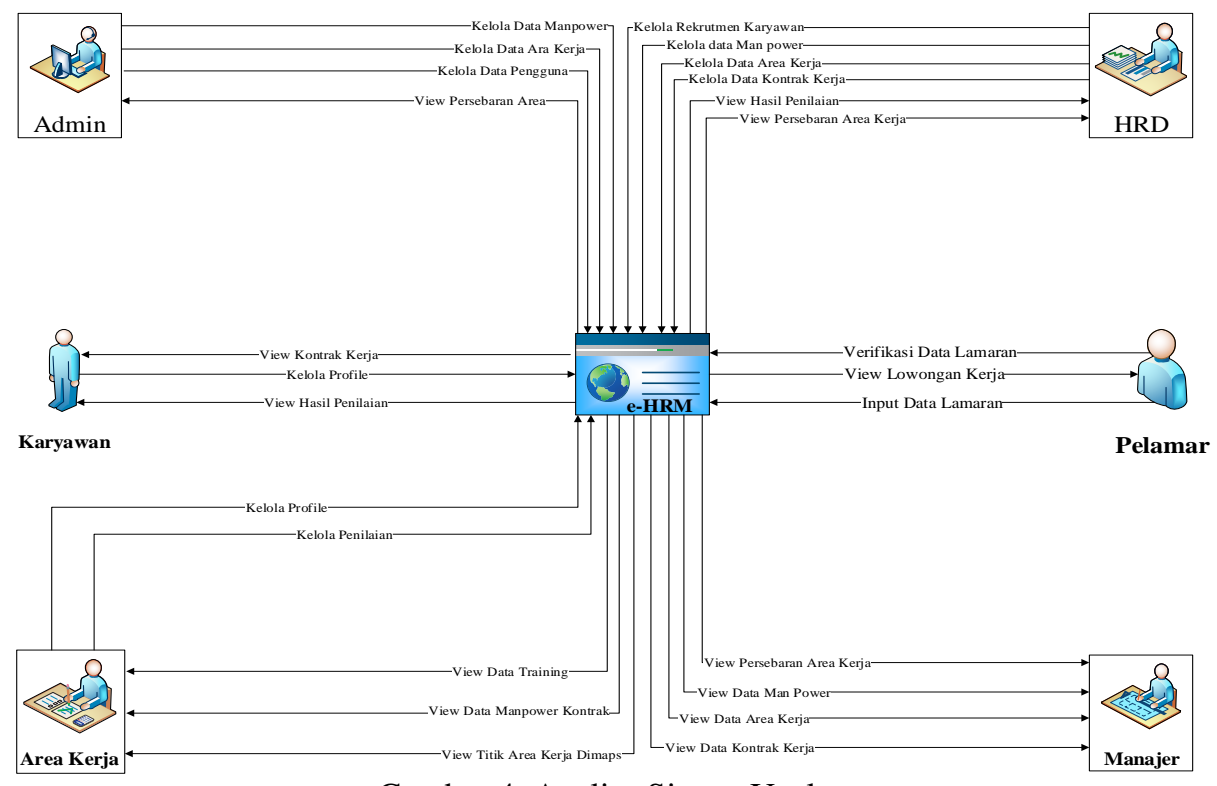

Gambar 4. Analisa Sistem Usulan 
Dari Gambar 4 diatas dapat dijelaskan bahwan rancangan sistem usulan berjalan dimulai dari ketika bagian HRD memasukkan pengumuman pengumuman lowongan pekerjaan sesuai dengan yang dibutuhkan oleh perusahaan. Pengumuman terdiri dari kualifikasi pelamar yang dibutuhkan dan pemberitahuan batas akhir pendaftaran. Pelamar membuka website e-HRM kemudian membuka menu info lowongan yang dimana didalam menu tersebut sudah tertera berita lowongan pekerjaan yang dibutuhkan oleh perusahaan. Bila pelamar ingin melamar pekerjaan, maka pelamar cukup masuk ke menu daftar kemudian mengisi form yang dibutuhkan selanjutnya pelamar akan mendapatkan kode aktivasi yang yang terdapat di kartu pendaftaran dan pesan singkat, kemudian pelamar masuk ke menu daftar kan memasukkan kode aktivasi dan mengisi form yang tersedia selanjutnya pelamar tinggal menunggu pemberitahuan pengumuman penerimaan berkas melalui pesan singkat.

Untuk proses penerimaan berkas pelamar yang dilakukan oleh HRD. HRD tinggal membuka menu data lamaran masuk dan melihat detail lamaran pekerjaan dan menentukan apakah pelamar tersebut diterima atau ditolak dan menetukan jadwal interview. Sistem akan secara otomatis mengirim pesan singkat kepada pelamar pemberitahuan jadwal interview. Setelah melakukan interview maka HRD akan menetukan jadwal training kepada pelamar dan sistem akan secara otomatis memberikan informasi kepada pelamar. Begitu juga dengan proses terakhir seleksi karyawan dimana dari hasil interview dan trainig karyawan bisa dinyatakan lulus menjadi karyawan dengan status karyawan belum kontrak.

Adapun proses terakhir adalah penentuan kontrak kerja karyawan dengan perusahaan penyedia jasa tenaga kerja. Selain itu sistem ini juga dapat mempermudah manager dalam melihat data-data karyawan, area kerja, kontrak kerja, penilaian dan persebaran titik-titik area kerja yang sudah bekerja sama. Bagi perusahaan yang sudah bekerja sama juga dapat melihat data-kata karyawan dan mengelola penilaian man power yang bekerja diperusahaan tersebut. Sistem ini juga mempermudah tugas HRD dalam menyajikan laporan kepada manager baik itu laporan man power, area kerja dan kontrak kerja man power.

Berikut ini merupakan use case diagram sistem usulan setiap aktor yang terlibat, dapat dilihat pada Gambar 5.

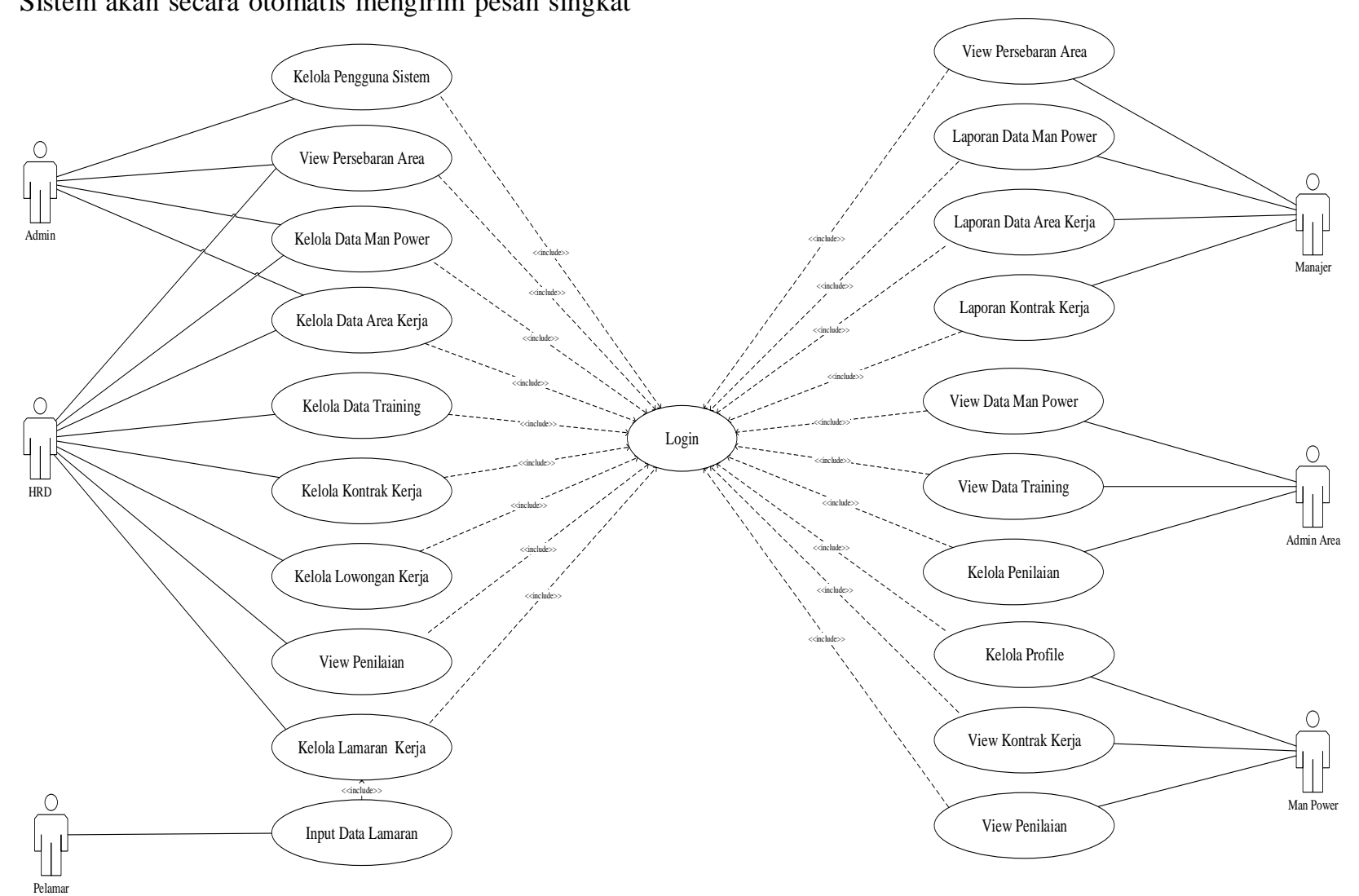

Gambar 5. Use case Diagram Sistem Usulan 
Jurnal Ilmiah Rekayasa dan Manajemen Sistem Informasi, Vol. 5, No. 2, Agustus 2019, Hal. 126-135

e-ISSN 2502-8995 p-ISSN 2460-8181

\section{E. IMPLEMENTASI DAN PENGUJIAN}

E.1 Hasil Implementasi Sistem

Adapun hasil implementasi sistem e-HRM pada

PT. Andesta Mandiri Indonesai dapat dilihat pada gambar dibawah ini.
Halaman utama merupakan halaman pertama kali yang ditampilkan ketika membuka sistem eHRM

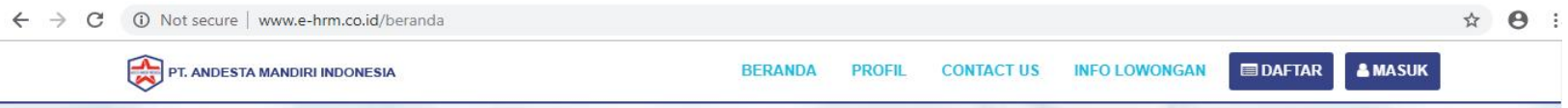

\section{Selamat Datang di PT. ANDESTA MANDIRI INDONESIA}

PT. AMI Merupakan suatu perusahaan outsourcing dibidang penyaluran tenaga kerja yang bertujuan untuk menjadikan perusahaan penyedia tenaga kerja yang terpercaya, terkemuka seta handal dalam bidang pelayanannya dan beroperasi sebagai penyedia tenaga kerja yang memiliki jaringan luas oleh tenaga kerja yang terampil, jujur, berdisiplin tinggi, dan bertanggung jawab serta memilikiperalatan dan perlengkapan yang modern

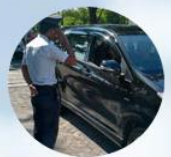

Security

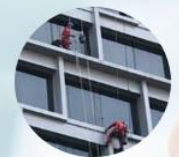

Facility Management

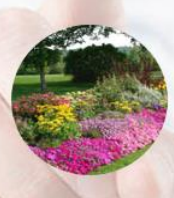

Landscape

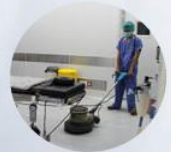

Cleaning Service

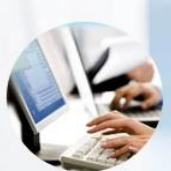

Office Support

Gambar 6. Halaman Utama

Terdapat menu beranda untuk tampilan awal, menu profil untuk melihat profil perusahaan, menu contact us untuk melihat informasi kontak perusahaan, menu informasi lowongan untuk melihat info lowongan yang tersedia, menu daftar untuk melakukan verifikasi data dan menu login yang digunakan untuk masuk kehalaman login.

$\leftarrow \rightarrow$ C (i) Not secure $\mid$ www.e-hrm.co.id/info_lowongan

BERANDA PROFIL CONTACT US INFO LOWONGAN

\section{OPEN RECUITMENT}

\section{PT. ANDESTA MANDIRI INDONESIA}

Dibutuhkan Tenaga Ahli Profesinal, Pekerja Keras disiplin dan Bertanggung jawab

\begin{tabular}{l} 
CeK Data Pedaftaran \\
\hline Lowongan \\
$\varangle$ CLEANING SERVICE \\
$\varangle$ MARKETING \\
$\varangle$ SECURITY \\
$\varangle$ GONDOLA
\end{tabular}

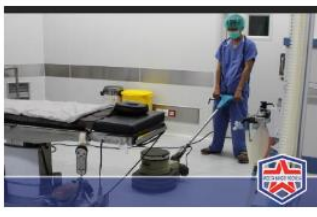

CLEANING SERVICE

Batas Pendaftaran : 23 Maret 2019 s/d 25 A pril 2019

Dibutuhkan Tenaga Profesional CLEANING SERVICE di PT. Andesta Mandiri Indonesia. Berikut merupakan deskripsi pekerjaan dan persyaratan Sebagai berikut

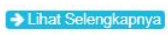

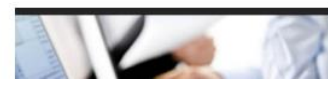

MARKETING

Gambar 7. Halaman Info Lowongan 
Halaman info lowongan merupakan halaman yang ditampilkan ketika membuka menu info lowongan. Halaman info lowongan berisi informasi lowongan yang tersedia dan juga terdapat status lowongan apakah masih di buka atau sudah di tutup dan juga terdapat batas pendaftaran setiap masing-masing lowongan. Pada halaman ini terdapat tombol lihat selengkapnya untuk melihat detail informasi dan persyaratan lowongan yang di inginkan.

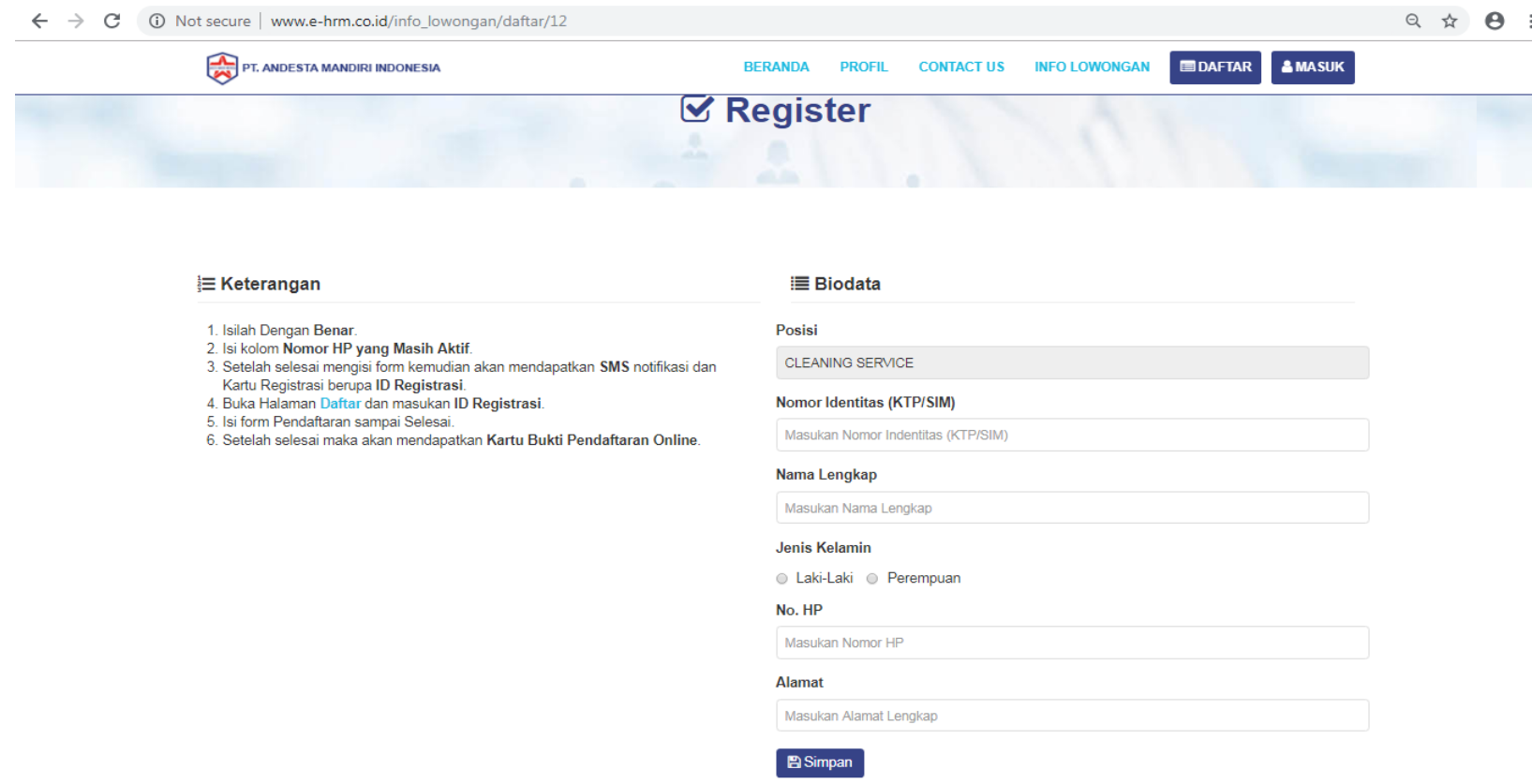

Gambar 8. Halaman Daftar Lowongan

Merupakan halaman yang tampil ketiga pelamar ingin mendaftar sebagai calon karyawan. Di halaman ini pelamar harus mengisi form-form yang tersedia sebagai tahap pendaftaran awal dan nanti pelamar akan mendapatkan pesan singkat notifikasi hak akses ke sistem untuk melakukan verifikasi data lengkap calon karyawan.
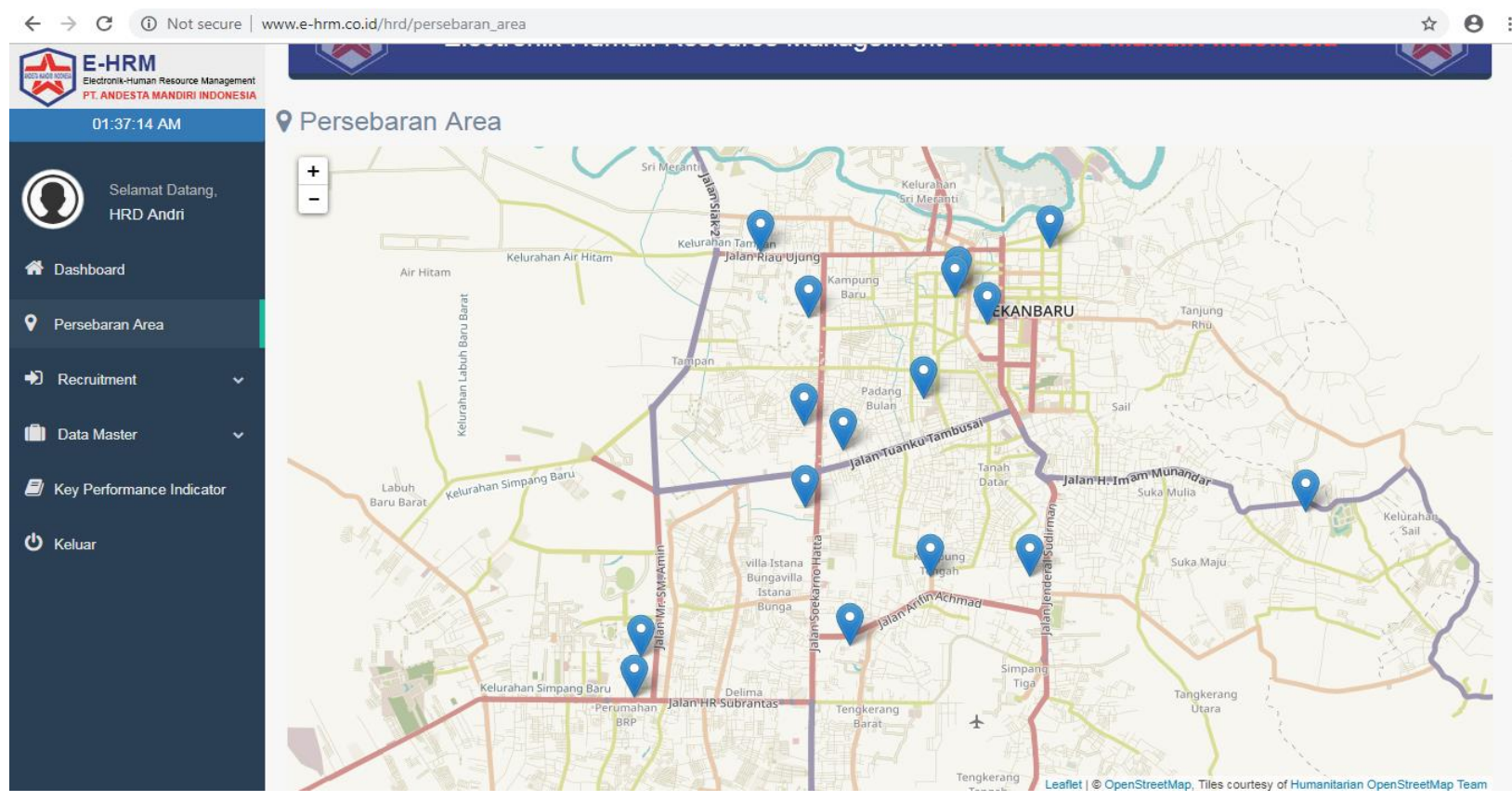

Gambar 9. Halaman Persebaran Area Kerja

Halaman persebaran area kerja merupakan halaman yang berisi titik-titik persebaran area kerja yang sudah bekerja sama dengan perusahaan. 
Jurnal Ilmiah Rekayasa dan Manajemen Sistem Informasi, Vol. 5, No. 2, Agustus 2019, Hal. 126-135

e-ISSN 2502-8995 p-ISSN 2460-8181

\section{E.2 Pengujian Sistem}

Pengujian dilakukan untuk meihat hasil implementasi, apakah sesuai dengan tujuan atau masih terdapat kesalahan-kesalahan. Metode pengujian menggunakan Black Box Testing. Bentuk pengujian ini untuk memastikan fungsi-fungsi yang ada pada sistem tersebut telah berjalan dengan baik dan sesuai dengan kebutuhan pengguna. Pengujian dengan blackbox dilakukan untuk menguji interface sistem, pengujian ini dilakukan untuk memperlihatkan bahwa fungsi-fungsi bekerja dengan baik dan dalam pengertian input sistem diterima dengan benar dan output yang dihasilkan sesuai dengan yang diharapkan. Hasil uji Black Box yang dilakukan terhadap fitur yang terdapat pada sistem e-HRM yang dibuat berjalan $100 \%$. Berdasarkan hasil pengujian yang telah dilakukan dapat diambil kesimpulan bahwa perancangan sistem e-HRM dapat berjalan dengan baik, sehingga sistem dapat mempermudah pihak perusahaan dalam melakukan proses management man power.

\section{REFERENSI}

[1] Djumialdji, F. X. (2006). "Perjanjian Kerja". Jakarta: Sinar Grafika.

[2] Kendall, K.E., dan J.E Kendall. (2010). “Analisis dan Perancangan Sistem" Edisi. 5. Jilid 1. Jakarta: Indeks.

[3] Pressman, R. S. (2010). "Rekayasa Perangkat Lunak". Yogyakarta: Andi.

[4] Whitten, Jeffrey L., et al. (2004). "Model Desain dan Analisis Sistem". Terjemahan Tim Penerjemah ANDI. .Edisi 6. Yogyakarta: Andi.

[5] Julianti, Lis. (2015). "Perlindungan Hukum Terhadap Tenaga Kerja Outsourcing di Indonesia".Jurnal Advokasi, Vol 5. No. 1.

[6] Sumarsono, Sonny. (2009) "Teori dan Kebijakan Publik Ekonomi Sumber Daya Manusia". Yogyakarta: Graha Ilmu.

[7] Biesalki, Eenst. (1997). "Knowledge Management and e-Human Reseorce Management".Yogyakarya:Forschungszentru m Informatik (FZI) \& DaimlerChrysler AG, Plant Wörth.

[8] Huub, R., dan B. Tanya. (2004). "e-HRM". innovation or irritation.

[9] Mangkuprawira, S. (2009). "Bisnis, Manajemen dan Sumber Daya Manusia”.Bogor: IPB Pres.

\section{F. KESIMPULAN}

Berdasarkan penelitian yang telah dilakukan pada PT. Andesta Mandiri Indonesia, maka dapat ditarik kesimpulan, dengan adanya sistem ElectronicHuman Resource Manajement (E-HRM) ini, dapat mempermudah tugas Human Resource Development (HRD) dalam mengelola data karyawan, data area kerja, kontrak kerja karyawan, lowongan kerja, lamaran pekerjaan, penilaian man power, dan pembuatan laporan. Sistem yang di bangun dapat mempermudah manajemen dalam proses recruitmen karyawan yang mana di mulai dari tahap informasi lowongan yang tersedia dan pendaftaran calon karyawan secara online. Sistem yang di bangun juga mempermudah manajemen mengetahui persebaran lokasi area kerja man power. Berdasarkan hasil pengujian Black Box yang dilakukan terhadap halaman Pelamar, Karyawan, Admin Area, Admin, HRD dan Manajer, dapat disimpulkan bahwa fitur yang terdapat pada sistem e-HRM 100\% dapat berjalan dengan baik dan tidak terdapat adanya kesalahan.

[10] Dessler, G. (2003). "Human Resource Management".Penerjemah Eli Tanya dan Budi S, edisi 9 jilid 2. Jakarta: Indeks Gramedia.

[11] Siswanto. (2002). "Manajemen Tenaga Kerja Indonesia". Jakarta: Bumi Aksara.

[12] Mathis, RL dan Jackson, JH. (2002). "Manajemen Sumber Daya Manusia". Jakarta: Salemba Empat.

[13] Sembiring, santoso. (2005). "Himpunan Peraturan Perundang-Undangan Republik Indonesia Tentang Ketenagakerjaan". Bandung: CV. Nuansa Aulia.

[14] Khakim, Abdul. (2003). "Pengantar Hukum Ketenagakerjaan Indonesia". Bandung: PT. Citra Aditya Bakti.

[15] Tanjaya, Evan J., dkk. (2016). "Pemetaan Surabaya Heritage dengan Geographic Information System". Jurnal Infra.

[16] Aswati, Safrian, dkk. (2017). "Studi Analisis Model Rapid Application Development Dalam Pengembangan Sistem Informasi". Jurnal Matrik. Vol. 16, No. 02. ISSN: 1854-4144.

[17] Kosaki, Sandy. (2015). "Penerapan Rapid Application Development Dalam Sistem Perniagaan Electronik Furniture". Citec Journal. Vol. 2, No. 4. ISSN: 2460-429. 